\title{
A Leader Without Followers? The Growing Divergence Between the Regional and Global Performance of Brazilian Foreign Policy
}

Andrés Malamud

\begin{abstract}
Brazilian diplomats and academics alike have long regarded regional leadership as a springboard to global recognition. Yet Brazil's foreign policy has not translated the country's structural and instrumental resources into effective regional leadership. Brazil's potential followers have not aligned with its main goals, such as a permanent seat on the UN Security Council and Directorship-General of the World Trade Organization; some have even challenged its regional influence. Nevertheless, Brazil has been recognized as an emergent global power. This article analyzes the growing mismatch between the regional and global performance of Brazilian foreign policy and shows how both theoretical expectations and policy planning were "luckily foiled" by unforeseen developments. It argues that because of regional power rivalries and a relative paucity of resources, Brazil is likely to consolidate itself as a middle global power before gaining acceptance as a leader in its region.
\end{abstract}

All regional powers that aspire to become global protagonists . . . must first be legitimated at the regional level since they do not possess enough material capacity or soft power to act autonomously in international politics. —Maria Regina Soares de Lima, Brazilian IR scholar, Fall 2008

No Governo Lula, a América do Sul será nossa prioridade. —Celso Amorim, Lula's foreign minister, January 1, 2003

$\mathrm{B}$ razilian diplomats and academics alike have long regarded regional leadership as a springboard to global recognition and influence. But while the strategic goal of becoming a legitimate regional leader has failed, the ultimate goal of becoming an intermediate world power has fared better. This article analyzes the growing mismatch between the regional and global performance of Brazil's foreign policy in order to answer two questions. First, what are the causes of this divergence? The explanation may be structural conditions-e.g., a larger and growing economy in regard to smaller or laggard neighbors; or policy behaviora change in the diagnoses or the perceptions of the Brazilian foreign policy elite, whose interests or confidence in the region may diminish 
as global opportunities arise. Second, what are the potential consequences of this mismatch? Either Brazil stays the course, reaching out to the region to bring it together and face the world with a single voice, or goes it alone.

The first part of this article tackles conceptual issues regarding leadership and power in international relations, setting the context to analyze Brazil's emergence as an intermediate global power and ensuing foreign policy changes. The second part shows that the hardships imposed by an unruly neighborhood and the preferential treatment conferred by world powers and institutions have led to a shift in Brazil's initial strategy, so that the country's external focus has become increasingly global. Brazil's regional influence is tested by measuring three dimensions: performance in region building, regional support for the country's extraregional goals, and the existence of contenders for regional leadership. Global influence is assessed by looking at Brazil's participation in top international groups and organizations. A summary of these findings shows that Brazilian foreign policy has increasingly combined damage control in the region with mounting global activism.

\section{LeAdership ANd Emerging Powers IN INTERNATIONAL RELATIONS}

Both "middle (or intermediate) power" and "regional power" are contested concepts, and attempts at rigorous theorization have led to a dead end (Hurrell et al. 2000, 1). However, these categories are widely utilized by practitioners and scholars. Following Thomas's theorem, let us take stock of their usage and refine their meaning so as to render them less vague and more analytically useful. ${ }^{1}$

Jordaan $(2003,165)$ defines middle powers as "states that are neither great nor small in terms of international power, capacity, and influence, and demonstrate a propensity to promote cohesion and stability in the world system." This definition is as useful a starting point as it is problematic. It is useful because it provides a basic, structural criterion, size, on which to build a more precise conceptualization; but it is problematic because it adds a second criterion, behavior, which is related not to structure but to agency.

Should a middle-sized state whose behavior is disruptive rather than conformist - say, Iran — not be called a middle power? Indeed, Jordaan excludes from his definition not only Iran but also Mexico, which is at odds with most of the literature. A further problem stems from his distinction between emerging and traditional middle powers, as the former are said to wield regional influence and could thus be called "regional powers." But is this a subtype of intermediate power or a different, if overlapping, category? According to Nolte, the difference between a 
regional and a middle power rests on leadership; hence, a regional power is a middle power that commands support within its region and recognition beyond it (Nolte 2007, 11, 15). Although this definition is static rather than dynamic, it does not seem to differ from Jordaan's "emerging middle power."

Yet the question remains what a middle power is. Keohane's classic answer is that a middle power is "a state whose leaders consider that it cannot act alone effectively, but may be able to have a systemic impact in a small group or through an international institution" $(1969,295)$. The "small group" seems to describe the strategy of emerging middle powers or regional powers, whereas the reference to an "international institution" more closely reflects the preferences of traditional middle powers. Kehoane's greatest insight, however, is to focus the definition not on the objective characteristics (of the state) but on the perception (of its leaders). Hurrell et al. later identify this feature as a promising way of rescuing the concept through a "constructivist route—-to see middle powers not as a category defined by some set of objective attributes or by objective geopolitical or geoeconomic circumstances, but rather as a selfcreated identity or ideology" $(2000,1)$.

Middle powership is thus understood as a social category that depends on recognition by others-peers and smaller states alike. Unsatisfactory as a definition based on actors' subjectivity rather than on objective characteristics may seem, we should remember that the very definition of which entities can be called states follows a similar logic: Monaco and San Marino are states not in accordance with the Weberian conceptualization but because of peer recognition.

As to leadership, it can be defined as the capacity to win and influence followers. It differs from hegemony: while the latter is better understood as the capacity of a powerful state (hegemon) to dictate policies to other states, leadership refers to the capacity to engage subordinate states so that they adopt the goals of the leading state as their own. (Paradoxically, this has also been called consensual hegemony; see Burges 2008.) This brings into focus the other face of leadership: followership. The relation between a leader and its followers can be collective- as when the former deals with the latter within a group such as a regional bloc; or it can be like a hub and spokes-as when the leader deals with followers individually. Potential followers can adopt three kinds of responses: bandwagoning, balancing, and resistance (be it foot dragging or fence sitting). Only bandwagoning nurtures leadership.

Social power, on which the potential to lead is based, is usually divided into three types: coercive or political, material or economic, and persuasive or ideological-normative (Etzioni 1975; Poggi 1990). In international relations, the first two are often paired, giving rise to a twofold classification: "hard power" is based on the utilization of structural (i.e. 
military or economic) means to influence the behavior or interests of others; and "soft power" refers to the ability to achieve a nation's goals through co-optation and attraction rather than coercion or payment (Nye 1990). Ideas, institutions, and exemplary behavior are the main instruments of the latter kind of power. Thus, Higgott $(2007,95)$ affirms that "leadership is not the same as economic and military preponderance. Leadership can be intellectual and inspirational as well."

Context and history deserve attention, because the nature of a middle power and the significance of regional leadership changed after the Cold War. In South America, where wars have been rare, power has perhaps a softer meaning than elsewhere, and policy options may thus be framed differently. Foreign policy analysis has to take these particulars into consideration and not assume perceptions and motivations from the general literature. It is also important to test the distinction, advanced by Jordaan, between traditional and emerging middle powers. While the former are said to be wealthy, stable, egalitarian, social democratic, and not regionally influential, the latter are allegedly poorer, socially troubled, regionally oriented (my emphasis), and reformist, but not radical. Although this reductionist scheme does not hold for some middle powers, it seems to fit Brazil. However, the country's regional orientation has not guaranteed successful regional leadership. In contrast to conventional accounts, this article makes the case that leading a region is not a precondition for global emergence.

\section{Between Regional Setbacks and Global ACHiEVEMENTS}

Brazil's major foreign policy aspiration has long been to achieve international recognition in accordance with its self-perception as a "big country" (Lima and Hirst 2006, 21). This gigantic nation-be it in territorial, population, or economic terms-has been categorized as an emergent power at least since 2001, when a Goldman Sachs report defined it as a BRIC country-one of the four emerging markets that were forecast to run the world economy by 2050 (Wilson and Purushothaman 2003). ${ }^{2}$ Brazil, Russia, India, and China, together with the United States, had previously been called "monster countries" (Kennan 1993). Unlike its companions, however, Brazil scares nobody. On the contrary, it has been defined as the "quintessential soft power" (Sotero and Armijo 2007, 43; see also Lima and Hirst 2006; Gratius 2007).

Having demarcated all its borders at the beginning of the twentieth century, Brazil neither makes nor receives territorial claims. Brazil's last major war was fought in 1865-70, when it aligned with its historical rival Argentina and tiny Uruguay to defeat Paraguay. It sent troops to Europe during both world wars but never again engaged in military 
conflicts in its own region. Despite its large armed forces and defense budget, which is the highest in Latin America, Brazil is not-and has no intention of becoming-a military power. ${ }^{3}$ Instead, it sees itself as a peace-loving, law-abiding, and benign power (Lafer 2001; Ministério da Defesa 2008).

These are the characteristics that its leaders have tried to build on to achieve a preeminent role on the regional and global stage. They have done this with largely positive-albeit heterogeneous-results. Brazil lacks the economic leverage to buy its way to regional or global leadership: although it is the largest Latin American economy, it is not the richest. Argentina, Chile, and Uruguay rank consistently higher in terms of GDP per capita and human development, and Mexico and Venezuela do so intermittently, depending on oil prices. This means that it is virtually impossible to sell to a domestic audience the importance of large money transfers from Brazil to neighboring countries, as this would sacrifice poor Brazilians to the benefit of richer foreigners.

\section{Regional Setbacks}

The absence of hard power instruments to pursue foreign policy goals despite Brazil's relatively rich endowments is aptly characterized by Sean Burges (2006) as "without sticks or carrots." Deprived of the structural resources of leadership, Brazil has had no choice but to resort to instrumental (or ideational) ones-hence the characterization of the country as a "soft power" promoting "consensual hegemony" (Burges 2008). But this is only part of the story. If it is true that the quest for regional influence has been conducted with velvet gloves, Brazil has deployed tougher-though not military-means to achieve global influence-replicating, albeit inverted, the regional-global duplicity highlighted by Pinheiro (2000, 327). Brazil's market size, export capacity, and investment weight have proved effective as bargaining chips in international negotiations.

As Hakim notes, compared to Mexico, the foreign policy of which is heavily influenced by and oriented toward a single country,

The Brazilian approach to foreign relations is very different. Its diplomats, politicians, and commentators write and speak about Brazil as a continental power. Pointing to its size and population, they argue that Brazil should be counted among the world's giant countries, alongside the United States, Russia, China, and India. Indeed, prior to his appointment as foreign minister a year ago, Celso Lafer argued that the interests of Brazil and these other "monster countries" ... go beyond specific issues and outcomes. They have a major stake-and therefore should have a major say-in how global affairs are managed. (Hakim 2002, 157) 
Because the country is smaller and less powerful than the other "monster countries," Brazil's ruling elites have believed it necessary to gain the support of the region in order to bolster their global claims (Almeida 2007; Hurrell et al. 2000; Lima 2008). This approach is consistent with the conventional argument that "it is the neighboring countries which have to sign up to the lead of emerging powers . . . in order to give them the power base necessary for regional as well as global power projection and international coalition building" (Schirm 2007, 6). Therefore, in the 1970s, Brazil started a slow but steady warming of relations with neighbors it had long neglected. The agreements with Paraguay and Argentina to build the Itaipú and Corpus power plants, the signing of economic agreements with Argentina that led to the establishment of MERCOSUR, and Brazil's prodemocracy activism during the 1990s paved the way for farther-reaching goals. In 2000, these ambitions crystalized into a new regional concept: South America. By substituting this for Latin America, Brazil tacitly recognized that it was unable to exert a significant influence on the whole continent and was thereby ready to focus on a smaller area, in accordance with two objectives: first, Mexico - the other Latin American giant and potential rival-was left out; and second, the countries included in the newly defined region were less dependent on the United States than those excluded, which gave Brazil broader room to maneuver.

To assess Brazil's performance as a regional and global player, there are three areas that merit inspection: the operation of Brazilian-led region-building projects; the degree of regional support for Brazilian goals within international organizations; and the existence and prospects of rival contenders for regional leadership.

\section{Collective Leadership: Erratic Attempts at Region Building}

MERCOSUR has been a keystone of Brazilian foreign policy since its inception in the early 1990s. Some years later, however, the government began to develop a strategy of enlargement to bring into the MERCOSUR fold all the other South American countries. In the Brazilian view, South America is not just a specific geographical region (different from Latin America as a whole) but also an autonomous political-economic area, given that U.S. influence recedes as distance from Washington increases. Brazil's elites consider this subregion to be within the country's natural sphere of influence (Souza 2008; CEBRI-CINDES 2007). Therefore, the Cardoso administration organized the first summit of South American presidents in Brasília in September 2000. Lula deepened this strategy, which led to the creation of the South American Community (SAC) at the Cuzco presidential summit of December 2004. The name was later changed to the Union of South American Nations 
(UNASUR), the constitutive treaty of which was signed in Brasília in May 2008. MERCOSUR arguably constitutes the inner circle of UNASUR.

MERCOSUR was initially a pragmatic integration project that dealt with trade, customs, and market access, but increasingly it has become a symbol for progressive political activism and leftist ideologies (Malamud 2005). In Brazil, it has turned into the flagship of those who stand for developmental, anti-imperialist, or nationalist ideas. To the most vocal of its supporters, MERCOSUR is not simply an economic association or a strategic instrument but a supranational identity that provides its member countries with the only way to survive in a globalizing world (Jaguaribe 2001). MERCOSUR's position as South America's core was officially established by the Lula administration, as the inaugural speech of Celso Amorim, its foreign minister, showed:

Under the Lula government, South America will be our priority. The relationship with Argentina is the pillar upon which MERCOSUR is built. [Without] the Common External Tariff and the Customs Union ... any pretension to negotiating together with other countries and blocs is a mere illusion. . . We consider [that] it is essential to deepen integration among the countries of South America. . . . The process of democratic change that Brazil is undergoing with the Lula government can be a source of inspiration and stability for the whole of South America [and] we will not shirk from contributing to the solution of situations of conflict. . . A politically stable, socially just and economically prosperous South America is a goal that must be pursued not just from a natural sense of solidarity, but also for the benefit of our progress and well-being. (Amorim 2003, author's translation)

Stability, justice, and prosperity of the surrounding states are referred to as goals that are both altruistic and self-interested. International negotiations without a consolidated customs union are seen as illusory, and region building as a priority. In short, regional integration is given precedence over further global action. As even a reputed critic of the administration admitted, the region was at the center of Lula's foreign policy: "Regional diplomacy, of which integration policy is a part, is certainly the foreign policy area that most distinguishes the Lula government" (Almeida 2005, 49). Yet results did not measure up to stated ambitions.

Just as the formula that led to the consolidation of the European communities involved a combination of liberalization (by France and others) and compensations (especially by Germany), the underlying formula of MERCOSUR was to obtain "preferential access into the Brazilian market in exchange for Argentine support for Brazilian international trade strategies" (Bouzas et al. 2002, 145). With the passing of time, however, mutual understanding between the two countries waned and 
cooperation decreased, giving way to growing suspicion. The implementation problems that emerged as a result were dealt with increasingly through unilateral measures, and "flexibility and a case-by-case focus [replaced] the enforcement of rules and established procedures" (Bouzas et al. 2002, 146).

Enlargement and institutionalization faced the same obstacles that plagued deepening. In 2006, a protocol was signed with Venezuela to grant it accession, but it has yet to be ratified by Paraguay. Similarly, several institutions have been created, but their autonomy and effectiveness remain dubious. The launching of the Initiative for the Integration of South American Regional Infrastructure (IIRSA) in 2000 and the creation of a Committee of Permanent Representatives in 2003, a permanent Court of Appeals in 2004, a Fund for MERCOSUR Structural Convergence (FOCEM) in 2005, and a common parliament in 2006 have not only had little impact but have actually served to disguise the significant shortcomings of the bloc, among them the absence of a regional budget and an agency that can represent common interests.

All this is not necessarily a drawback for Brazilian interests. Indeed, some observers argue that Brazil's interests are best served by not relinquishing any sovereignty to regional bodies. But it certainly deals a blow to Brazil's leadership, as the undertaking it officially values most is far from thriving. The perception that MERCOSUR is becoming a burden rather than an asset has led some politicians, among them two-time presidential candidate José Serra, to call for the common market to be downgraded to a free trade zone. The argument is that Brazil will be more capable of pursuing its foreign goals on its own rather than depending on costly agreements with unpredictable partners (O Globo 2010).

UNASUR aims to unite two existing regional free trade blocs, MERCOSUR and the Andean Community, as well as to integrate Chile, Guyana, and Surinam. The scheme was originally devised to serve Brazil's goal of redefining its area of influence as South America. However, it was later hijacked by President Hugo Chávez and has become a Venezuelan rather than a Brazilian instrument. The cities chosen to host the future institutions of this bloc, Cuzco and Cochabamba, reflect identity claims rather than functional concerns and pay lip service to the autochthonous discourse of Chávez and his regional allies, whose understanding of the organization differs considerably from Brazil's. In sum, neither MERCOSUR-because of its malfunctioning-nor UNASUR — because of ideology and rivalry-has turned out to be a solid springboard for Brazilian leadership. Instead, MERCOSUR has stagnated, and UNASUR has yet to become more than a "photo-op" forum in which the Bolivarian impetus is at least as significant as Brazil's more pragmatic influence. 
The conditions that may foster or limit regional integration processes depend on demand (derived from potential common gains), supply (i.e., leadership), and inertial (i.e., institutional) conditions (Mattli 1999; Malamud and Castro 2007). Inertial conditions are demand or supply conditions that become institutionalized, locking in previous agreements and creating path-dependent effects. In South America, a low level of all these explains not only regional underperformance but also the free-riding behavior of prospective leaders and followers alike (Burges 2005, 2006).

\section{Lack of Regional Support for Brazil's Global Goals}

Brazil has long aspired to a permanent seat on the United Nations Security Council. In 2004, a high-level committee submitted to the UN Secretary-General a proposal that called for the establishment of new permanent members. Four countries-Brazil, Germany, India, and Japan, the so-called G-4-promptly joined efforts to grab the new seats.

Many countries in the world have expressed support for some but not others in this group. But a larger group formed to oppose the creation of any new permanent seats and proposed the introduction of semipermanent membership. This assemblage, which was initially called the Coffee Group and later renamed Uniting for Consensus, brings together the G-4's regional rivals. Argentina and Mexico were among its leaders, together with Italy, South Korea, and Pakistan. As it turned out, aspiring UNSC members could not persuade their home regions to support their bids for international recognition (Arraes 2006, 27-40). Though not a surprise, the position of Argentina, Brazil's main regional partner, as the staunchest opponent of its main international ambition dealt a heavy blow to Brazil's image as a regional leader.

Also under the Lula administration, Brazil put forward a candidate for the post of director-general of the World Trade Organization (WTO). Early in 2005, there were four contenders: one from the European Union (Pascal Lamy), another from Mauritius, and rather embarrassingly, a third from Uruguay, as well as the Brazilian candidate, Luíz Felipe de Seixas Corrêa. This showed not only that MERCOSUR was unable to agree to a joint candidate but also that Brazil could not even gather majority support for its position (as Argentina supported the Uruguayan candidate). To add insult to injury, the Brazilian nominee was eliminated in the first round, while the Uruguayan, Carlos Pérez del Castillo, made it to the last. This internal quarrel did not damage Brazil's reputation and influence in the WTO, but it showed that the prospects for building a regional consensus to support its global goals were bleak.

Just a couple of months later, Brazil suffered another blow to its aspirations to rally the region behind a nominee for a top international 
post. In July 2005, two candidates ran for the presidency of the InterAmerican Development Bank (IDB): Colombia's ambassador to the United States, Luis Alberto Moreno, and Brazilian former planning minister João Sayad. Analysts expected the election to be a divisive and difficult one, with the United States and Mexico backing Moreno and much of South America rallying behind Brazil's candidate. However, Moreno won the support of a majority of Central American and Caribbean countries, which ensured his quick victory. The election, held behind closed doors at the IDB's Washington headquarters, lasted about two hours and delivered a sound defeat to Brazilian diplomacy, not least because the winning rival was also South American.

In contrast to that episode, Brazil did gain regional support for its goal of heading the UN Stabilization Mission in Haiti (MINUSTAH). Officially, the Brazilian authorities linked the country's presence in Haiti with the aim of obtaining a permanent seat on the Security Council, or at least having a bigger say in the United Nations (Gauthier and John de Sousa 2006). Although Brazil's real motives were more complex, most did relate to its international ambitions.

Brazil acted in Haiti in response to several motivations. As UNSC nonpermanent members, Brazil and Chile worked side by side for the approval and renewal of the MINUSTAH mandate in 2004. . . . Brazil also sought to diminish CARICOM's, Venezuela's and Mexico's opposition to MINUSTAH. For Brazilian foreign policy discourse, presence in Haiti meant to replace old times nonintervention policy for present non-indifference policy (Hirst 2007, 7).

Thus Brazil exhibited leadership attributes by signaling the adoption of a new foreign policy to its neighbors, working together with its main partners in South America, showing its capacity to project power abroad, and demonstrating that it could legitimate a military intervention in the eyes of other countries in the region. And although these actions were initially controversial at home, this strategy worked. Regardless of the results of the mission in Haiti, there Brazil was effectively recognized as a regional leader. But this was hardly enough to cement its higher ambitions; worse, the 2010 earthquake devastated not only Haiti but also the one thing Brazil had succeeded at in Latin America.

\section{Hub-and-Spokes Leadership: Prospective Followers and Power Contenders}

There are two countries in Latin America that are in a structural position to dispute Brazilian claims to leadership: Argentina and Mexico. Both have sizable economies, large territorial landmass and population, rich 
natural resource endowments, and a record of intermittent international activism. Moreover, both relentlessly pursue the diplomatic goal of impeding any single country from "representing" the whole region. Their leading role in the Uniting for Consensus group and their participation with Brazil in the G-20 (the only Latin American countries in the forum) testify to their international standing as well as their determination not to be left behind by their bigger neighbor.

One of Brazil's responses to this competition has been to exclude Mexico from its redefined region. In his inauguration speech, Foreign Minister Amorim listed Mexico after South America, the United States, and the European Union, together with other so-called "large developing countries," such as China, Russia, India, and South Africa. It would appear, then, that to the Itamaraty, Mexico can no longer be considered a regional rival: it belongs to another region.

It is not so easy for Brazil to similarly dispatch Argentina, officially recognized as its main regional partner. For Argentina, however, this partnership is based on equality of standing rather than on Brazilian supremacy. Indeed, Argentine leaders have even considered their country as a legitimate contender for regional leadership, and have promoted closeness with the United States or other circumstantial allies (Venezuela most recently) in order to counterbalance Brazil's power (Russell and Tokatlian 2003).

Argentine ambivalence toward its neighbor wanes when times are good and waxes during times of economic hardship, independently of which party is in government. In the 1990s, Peronist president Carlos Menem was one of the founders of MERCOSUR, but simultaneously aligned Argentina with U.S. foreign policy. Likewise, in the 2000s, Peronist presidents Néstor and Cristina Kirchner cultivated excellent relations with the Lula administration but also struck a close alliance with Venezuelan president Chávez. Argentina has political ambitions similar to Brazil's, and it has nurtured recurring economic grievances against Brazil, which have given rise to spasms of protectionist behavior and have hindered further integration. As long as these competing aspirations and neighborly fears persist, trying to win Argentine support for Brazilian leadership is tantamount to "sleeping with the enemy."

As regards Venezuela, the official line is that Brazil is "not competing for the leadership of South America. ... [However, it is] engaged in a contest for leadership . . . each offering a different vision of how the regional geopolitical, geo-economic, and ideological space should be organized and directed" (Burges 2007, 1343). This contest for leadership is neither structurally nor historically determined, as Venezuela has never been one of the "big" Latin American countries. Indeed, it has promoted divergent strategic goals, and its policies are based on the utilization of oil wealth as a means to build political alliances. ${ }^{4}$ 
In spite of this weak power base, Chávez has developed a high-profile foreign policy, which is based largely on vilifying the United States in much the same way that the Iranian ayatollahs did (Chávez called George W. Bush "the devil" in a famous U.N. speech). Furthermore, following the principle that "my enemy's enemy is my friend," Chávez has toured the world several times to meet with the leaders of such revisionist countries as Russia, Belarus, Syria, Libya, and Iran-not to mention Cuba, which Chávez holds up as a model.

All these dubious alliances notwithstanding, the main challenge to Brazilian leadership posed by Venezuela is not global but regional. Chávez has courted and "bought" the loyalty of countries purportedly in the Brazilian sphere of influence, such as Bolivia and Ecuador, and he even tried his luck with Paraguay. Venezuela's capacity to win some regional support with a stance that diverges from Brazil's has challenged Brazilian leadership. In the long run, an oil-based foreign policy is limited by the vagaries of international prices; but in the short term, Brazil's ability to control its neighbors has been seriously impaired.

As for Paraguay, traditionally this country has sought to maintain a balance in its relations with its two giant neighbors, Brazil and Argentina. Over the years, however, it has also kept close ties with the United States. Recently, these have included permitting U.S. troops to engage in military maneuvers on Paraguayan soil and the opening of an FBI office at the U.S. embassy in Asunción. Reports say that 46 U.S. military operations have been conducted in Paraguay since 2002, including visits, special exercises, and humanitarian missions, especially in the areas close to Ciudad del Este, in the triborder region (Inter Press Service 2005).

In response to this development, Brazilian troops have staged frequent exercises along the border, sometimes crossing the frontier and provoking Paraguayan protests. The administration of Fernando Lugo (2008- ) has questioned the current distribution of benefits and energy generated by the Itaipú Dam, and this has further embittered relations; a mutually satisfactory agreement has not been easy to strike. An additional headache for Brazilian diplomacy is that Paraguay is one of the 23 countries in the world (and the only one in South America) that maintains diplomatic relations with Taiwan rather than with the People's Republic of China. Since 1957, Taiwan has become Paraguay's main international donor, offering cash to finance agricultural, educational, and social projects and paying entirely for the construction of a new house of parliament. The unintended consequence of this bizarre relationship_one that hurts Brazilian aspirations to establish closer relations with a key global power-is that it prevents MERCOSUR from signing international treaties with China.

Uruguay, the smallest member of MERCOSUR, nurtures resentment toward Brazil for two reasons. The first is MERCOSUR's low perform- 
ance and its bias against the smaller economies, compounded by the straitjacket it imposes by denying member states the possibility of individually signing trade agreements with third countries (Vaillant 2007). The second is Brazil's refusal to intervene in Uruguay's border conflict with Argentina over the building of a pulp mill. This conflict led a group of citizens from the Argentine city of Gualeguaychú to block one of the three bridges that unite the two countries by land. The blockade was in place from April 2005 to June 2010, in violation not only of Argentine laws but also of the MERCOSUR treaties. However, Brazilian authorities argued that this was a bilateral issue and stuck to a hands-off policy. Sergio Abreu, an Uruguayan leader and one of the first negotiators of MERCOSUR, contended in a parliamentary speech that Brazil had a responsibility.

In this regard, it is not just Argentina that does not meet its commitments but also Brazil, which forgets its responsibility within MERCOSUR and distances itself from the basic principles inherited from the Baron of Rio Branco; namely, prioritizing its relations with the River Plate and adequately managing its interests with the United States. . . . With the delusions of grandeur that Brazil indulges in under the current Foreign Minister, membership on the Security Council and the Group of Seven and leading the World Trade Organization are its priorities. (Abreu 2006)

In spite of Uruguay's hints that it would sign a free trade agreement with the United States, the U.S. administration decided not to intervene in a way that could damage Brazil's reputation or leadership. However, it agreed to sign a Trade and Investment Framework Agreement (TIFA), which crowned the Uruguayan decision to leave the door open for a Chilean-style policy of international insertion through multiple bilateral agreements rather than through exclusive membership in a regional bloc. The United States has also become the main destination for Uruguayan exports, which further highlights the deterioration of Uruguay's trade links with both of its large neighbors.

Bolivia has posed one of the toughest challenges to Lula's "strategy of patience" and to Brazil's policy of foreign investment and energy integration. The dependence of São Paulo's giant industrial complex on Bolivian gas adds stress to a relationship already complicated by blurry territorial borders. The sudden decision in 2006 by the recently inaugurated president, Evo Morales, to send troops to guard dozens of plants, refineries, and pipelines and to give foreign companies-including, conspicuously, Brazil's Petrobras-six months to renegotiate their contracts or get out, signaled the new combative stance his administration would pursue with regard to foreign investors. What is worse, it underscored a growing affinity with Venezuelan president Chávez, who had already 
cracked down on foreign firms and allegedly had offered technical assistance to help Bolivia manage its nationalized companies.

Lula called an emergency cabinet meeting, and Petrobras, whose investment in the decade since Bolivia privatized its energy sector had helped that country to quadruple its gas reserves, called the measure "unfriendly" and threatened not to make new investments. Opposition leaders cried that Brazil had been humiliated and asked the president to toughen his stance, which Lula refrained from doing. Instead, he stated that the Bolivian government had made a sovereign decision and pledged that his country would respect it. However, the event made it clear that Bolivia was no longer a reliable partner or energy source. Since then, the Brazilian government has accelerated its goal of reaching energy self-sufficiency at the earliest possible date.

Brazilian relations with Ecuador have also turned sour on occasion. In September 2008, President Rafael Correa expelled the managers of Odebrecht, a Brazilian engineering company, which he accused of bribery and of constructing a flawed power plant. Not only did Correa declare that his country would not compensate the company for what it had already built, but he also refused to repay the US\$243 million loan that Brazil's national development bank, the BNDES, had lent Ecuador for that purpose. The fact that Ecuador had also defaulted on some of its bonds that same month did not make the Brazilian government any happier. The decision led Brazil to recall its ambassador, an unprecedented measure.

There was much speculation about why Correa would have antagonized a friendly power, an action that also risked Ecuador's access to foreign credit. Analysts referred to the poor state of Ecuador's public finances and to rumors that Correa had opted to act preemptively because of the imminent disclosure that Odebrecht had funded his electoral campaign. Whatever the reason, this crisis shook the foundations of the ALADI trading system (the Latin American Integration Association) and made the Brazilian authorities realize that, for some neighbors, it was Brazil rather than the United States that was the new "imperialist" power. In December 2008, Foreign Minister Celso Amorim declared that his government would revise its policy of granting loans to any South American partners that contested their debts, adding threateningly,

I hope that all those countries have many other sources of credit and foreign earnings to continue to make progress. . . . They cannot continue to treat Brazil like a colonial power that wants to exploit them. We follow the rules of the international market and if they don't think those rules are good, they can start a discussion. (Amorim 2008)

Lula's top foreign adviser, Marco Aurélio Garcia, a usually conciliatory and soft-spoken envoy to the region, did not mince his words either. 
What I observe is that the Ecuadorian government committed a very serious mistake. It does not seem to us that this is up to the standard of relations between Brazil and Ecuador. . . . If a friendly government treats us this way, what should we expect from our enemies? (Garcia 2008)

In the end, Ecuador agreed to disburse the next due payment, and Brazil reinstated its ambassador. Nevertheless, the affair emphasized that Brazilian money may well be welcome but is insufficient to buy consent. On the contrary, it can generate resentment. To many civil society organizations and social movements,

Brazilian protagonism . . . is interpreted politically as an expression of economic expansionism, above all when the involvement of the National Bank of Economic and Social Development and . . . the performance of the large civil construction companies and Petrobras are at stake. (Vaz 2007, 34)

In contrast with the cases described above, Peru and Colombia have turned out to be friendlier partners for Brazilian interests than might have been expected. But Brazil is not as significant for these countries, which are also courting an extraregional heavyweight, the United States. For Colombia in particular, the partnership with the United States is crucial to its hopes of winning back large parts of the national territory that have fallen into the hands of guerrilla forces and drug gangs. Although the United States is not very vital a partner for Peru, the latter has cultivated increased commercial relations with Asia-mainly China and Japan-rather than with Brazil.

Chile, last but not least, is as reliable a partner as Brazil can hope to find in the region. Alas, though, Chile is as reliable in its relations with Brazil as it is in its relations with everyone else, since the country has sought to carve out for itself a position as a respectable global player by abiding by international law and contracts. Although both countries have participated in the MINUSTAH since 2004, and although their economic and diplomatic relations are excellent, Chile's global rather than regional orientation - and its lack of territorial borders with Brazil-has limited the potential for cooperation.

South America thus has countries that are either ambivalent about Brazil-seeing it as a mix between a welcome paymaster and a new colonial power-or have only minor shared interests, or both. What is worse, there are a handful of rivals for leadership, either consciously (Venezuela or Argentina) or less consciously (the United States and even Taiwan). 


\section{Brazil's Global Achievements}

Brazil's most resounding international disappointment has been its failure to obtain a permanent seat on the United Nations Security Council. This long-nurtured ambition was positively fed in 2005, when then-U.N. Secretary-General Kofi Annan called for a consensus to expand the council from 15 to 24 members. A report presented by a committee of experts that year put forward two alternatives to implement this reform (United Nations 2005). One proposed the appointment of 6 new permanent members, and the other called for the creation of a new class of members, with 8 countries serving for four years, subject to renewal. Neither plan was put into practice, but these blueprints provoked broad contestation and led to the formation of the Uniting for Consensus group, which preferred no change to reforms that might favor rival neighbors. Because it was clear that this was a core Brazilian foreign policy goal, this lack of support was seen as a fiasco. But this is an exception, as Brazilian global foreign policy has experienced many more successes than failures.

Perhaps one of the factors that most boosted Brazil's foreign reputation was its sudden promotion as a BRIC country (Armijo 2007). A report by the investment firm Goldman Sachs predicted that the combined economies of these countries would eclipse those of the current richest countries of the world by 2050 because of their rapid growth rates (Wilson and Purushothaman 2003). The report did not advocate the creation of a BRIC economic bloc, but there are mounting indications that the four BRIC countries have sought to form a "political club" and thereby convert their growing economic power into greater geopolitical stature. Notably, the presidents and foreign ministers of the BRIC countries held exclusive meetings on the sidelines of a variety of forums during 2008 and started to convene exclusive annual meetings in 2009.

IBSA is a more limited and "principle-oriented" grouping. This acronym refers to the trilateral developmental initiative between India, Brazil, and South Africa to promote South-South cooperation and exchange (Vizentini 2006, 178-89). Following discussions between top IBSA government officials at the G-8 meeting that took place in Evian in 2003, the three foreign ministers met in Brasilia on June 6, 2003. At this meeting, the IBSA Dialogue Forum was officially launched with the adoption of the Brasília Declaration. This group has been publicized not only as a South-South initiative but as one that brings together the largest democracies on every continent of the Southern Hemisphere (Saraiva 2007). It therefore conveys more powerfully than the BRIC the Brazilian foreign policy banners, such as democracy, respect for human rights, and the peaceful resolution of conflicts. Indeed, its main strategic goal has been aptly defined as soft (Flemes 2007). 
Brazil has been most skillful in the realm of commercial negotiations. Although the current WTO round has stagnated, a new collective actor has emerged from it: the Group of 20 (G-20). Variously called the G-21, G-22, or G-20+, this is a bloc of 20-odd developing nations that came together at the fifth ministerial WTO conference in Cancún, Mexico in 2003. It collectively represents 60 percent of the world's population, 70 percent of its farmers, and 26 percent of world's agricultural exports. Its origins date back to June 2003, when the IBSA foreign ministers signed the Brasília Declaration, which stated that the developed countries were acting to protect their less competitive sectors and emphasized that their goal was to promote the reversal of such protectionist policies and trade-distorting practices. In the document, the "Ministers of India and South Africa thanked the Brazilian Minister for convening this first trilateral meeting," which made clear that Brazil was not a minor partner but a leading force in the group (Vizentini 2006, 169-77). This became even clearer in 2008, when the Doha Round, albeit unsuccessful, came to a close with febrile negotiations between four actors: the United States, the European Union, India, and Brazil. This dynamic was reiterated at the Copenhagen Summit on Climate Change in December 2009, at which the leaders of China, India, Brazil, and South Africa negotiated the final declaration with U.S. president Barack Obama, excluding the European Union, Russia, Japan, and other global powers.

Probably the most select international club after the UNSC, the Group of Eight (G-8) has been the most influential when it comes to the global economy. It is a forum for eight nations of the northern hemisphere: Canada, France, Germany, Italy, Japan, Russia, the United Kingdom, and the United States, plus the European Union. The G-8 organizes annual summit meetings of its heads of government, and various ministers also meet throughout the year. In the last decade, some members expressed a desire to expand the group to include five developing countries, referred to as the Outreach Five (O-5) or the Plus Five: Brazil, China, India, Mexico, and South Africa. These countries had participated as guests in previous meetings-the so-called G- $8+5$. The latter were institutionalized in 2005, when then-Prime Minister Tony Blair, as the host of the G-8 summit at Gleneagles, Scotland, invited the leading emerging economies to join the talks. The hope was that this would consolidate a stronger and more representative group that would reenergize the trade talks at Doha and promote deeper cooperation on climate change; hence Brazil became a permanent member of yet another world-class international organization. It is also a member of the "other" G-20 (more formally, the Group of Twenty Finance Ministers and Central Bank Governors), a group of 19 of the world's largest national economies plus the European Union. This group also met twice at the 
heads of government level in November 2008 and March 2009 in the wake of the world financial crisis. In the former event, Brazil played a high-profile role as it hosted the preparatory meeting.

A last conspicuous sign of international recognition of Brazil as an emerging power and regional representative was the European Union's 2007 invitation for a "strategic partnership." This is notable because the EU had been reluctant to engage other Latin American countries-especially those of MERCOSUR-individually. The EU's strategy was to increase the legitimacy of its integration model by fostering similar projects beyond its borders through bloc-to-bloc interregional negotiations. Singling out one country constituted recognition of Brazil's rising star as much as acknowledgment of the futility of previous European illusions about the future of Latin American regionalism.

Over the last years, Brazil has become an increasingly significant global player and emerged as a key interlocutor for the EU. However, until recently EU-Brazil dialogue has not been sufficiently exploited and carried out mainly through EU-MERCOSUR dialogue. Brazil will be the last "BRICS" to meet the EU in a Summit. The time has come to look at Brazil as a strategic partner as well as a major Latin American economic actor and regional leader. . . . Its emerging economic and political role brings new responsibilities for Brazil as a global leader. The proposed strategic partnership between Brazil and EU should help Brazil in exercising positive leadership globally and regionally. ... Over the last few years Brazil has emerged as a champion of the developing world in the UN and at the WTO. . . . A quasi-continent in its own right, Brazil's demographic weight and economic development make it a natural leader in South America and a key player in Latin America. Brazil is now actively pursuing this role in the MERCOSUR framework and is at the forefront of the drive to promote the Union of South American Nations (UNASUR). . . . Positive leadership of Brazil could move forward MERCOSUR negotiations (European Commission 2007, 1).

Although the EU did not intend to harm MERCOSUR or its relations with that group, its pompous rhetoric had negative repercussions. By calling Brazil a "regional" and "global" leader, a "champion of the developing world," a "quasi-continent in its own right," and "a natural leader in South America," it damaged its own position and that of Brazil regarding the other South American countries (Saraiva 2009). Once again, global success has proven to be antithetical to regional leadership.

\section{Conclusions}

In spite of its regional preeminence, Brazil has been unable to translate its structural and instrumental resources into effective leadership. Its potential followers have not aligned with Brazil's main foreign policy 
goals, such as its pursuit of a permanent seat on the UNSC, of the WTO Directorship-General, or of the IDB presidency, and some have even challenged its regional influence. By playing the regional card to achieve global aims, Brazil has ended up in an unexpected situation: while its regional leadership has grown on paper, in practice it has met growing resistance. Yet the country has gained increasing global recognition. Today, Brazil is acknowledged as an emergent global player by the established world powers, such as the G-8 members and the European Union. This article has analyzed the mounting mismatch between the regional and global recognition of Brazilian status. Due to lasting cleavages, divergent interests, and power rivalries in South America, the mismatch is not likely to be bridged anytime soon.

Paradoxically, however, if the Brazilian quest for regional leadership has been unsuccessful, promoting it has been beneficial for Brazil's national interests. This paradox has lately come to the attention of the country's foreign policy elite, which is increasingly advocating a more pragmatic stance based on diversified strategies to minimize dependence on a troublesome region (CEBRI-CINDES 2007). Although subregional integration has not ceased to be a goal, it is no longer a priority (Vigevani et al. 2008). Furthermore, the increasing pluralization of actors with a stake in foreign policy (Cason and Power 2009) may also be making Brazil more globally_as opposed to regionally-sensitive.

The Brazilian bid for leadership has been hindered by several factors, which can be understood in light of the concepts presented in the first section of this article. The structural components of its leadership project (i.e., military power and economic might) have been insufficient to cajole or buy support, especially facing rivals such as Venezuela, the United States, and even Taiwan, which are willing to give money or military support to win over undecided followers. The instrumental components of leadership have been either unavailable or insufficient. Brazil is reluctant to build common institutions because it feels they would tie it to unreliable neighbors rather than consolidate regional integration. In terms of ideas and values, its regional strategies look to some neighbors like hegemonic incursions rather than enlightened leadership based on the pursuit of shared interests. And regarding higher education and migrant destinations, the main attractors for most South American countries continue to be extraregional powers; namely, the United States and Europe.

To be sure, Brazil has not become indifferent to the region. However, its ambitions are increasingly defensive rather than offensive. The main goal is no longer to integrate South America into a regional bloc with a single voice but to limit damages that could spill over its borders or stain its international image as regional pacifier. Now, it seems sufficient to stabilize the region and prevent political instability, economic turmoil, and 
border conflicts. The name of the game is to keep quiet rather than lead the neighborhood, since preventing trouble in its backyard seems to be a necessary condition for Brazil to consolidate its global gains.

Given that Brazil is not a revisionist power that intends to upset the system but rather a reformist one that wishes to enter it, damage control has become its central task. This has turned a would-be leader into a fireman or, as Carlos Quenan once paraphrased from economics jargon, a leader of last resort. Thus, as The Economist (2008b) aptly remarked, "it may be the rising power in the Americas but Brazil is finding that diplomatic ambition can prompt resentment." By trying to mitigate this resentment, the country may find itself closer to the category of a traditional rather than an emerging middle power. In other words, it can aspire to a leading role on the global stage as long as it goes it alone.

\section{NOTES}

Previous versions of this article were presented at the Colóquio Internacional Brasil-União Europeia-América do Sul, Anos 2010-2020, University of Brasília, October 8-10, 2008; and at the 27th Latin American Studies Association Congress, Rio de Janeiro, June 11-14, 2009. I am grateful to Octavio Amorim Neto, Alexandra Barahona de Brito, Sergio Caballero, Kathryn Hochstetler, Andrew Hurrell, Federico Merke, Timothy Power, Miriam Gomes Saraiva, William C. Smith, Alcides Costa Vaz, Tullo Vigevani, Eduardo Viola, and two anonymous reviewers for their comments. I also acknowledge the Portuguese Science Foundation (FCT) for its financial support of the research used for this article under the project PTDC/CPJ-CPO/099290/2008. Alexandra Barahona de Brito assisted with translations and editing.

1. The American sociologist William Isaac Thomas in 1928 postulated that "if men define situations as real, they are real in their consequences."

2. Brazil's performance and emergence as a global power has been acclaimed by top specialized media sources. See Economist 2008a; Newsweek 2008; Wall Street Journal 2008, 2009.

3. In 2005, Brazil's military budget doubled Colombia's, tripled Chile's, quadrupled Mexico's, and was eight and ten times higher than Argentina's and Venezuela's, respectively (IISS 2006). In 2007, it exceeded all its South American counterparts combined (CEUNM 2008).

4. In 2006, oil made up 89 percent of Venezuela's total exports and 56 percent of its fiscal revenues (Alvarez 2007, 269).

\section{REFERENCES}

Abreu, Sergio. 2006. Protocolo de adhesión de Venezuela al MERCOSUR. Exposición en oportunidad de su aprobación en el Senado. Uruguay, Cámara de Senadores, October 31. www.sergioabreu.com/adm/parlamento.php?id=88 Almeida, Paulo Roberto. 2005. Políticas de integração regional no governo Lula. Política Internacional [Lisbon] 29: 33-60. 
2007. Brazil as a Regional Player and an Emerging Global Power. FES Briefing Paper 8. July. São Paulo: Friedrich-Ebert-Stiftung.

Alvarez, Angel E. 2007. Venezuela 2007: los motores del socialismo se alimentan con petróleo. Revista de Ciencia Política (Santiago) 27: 265-89. Special Issue.

Amorim, Celso. 2003. Discurso proferido pelo Embaixador Celso Amorim por ocasião da transmissão do Cargo de Ministro de Estado das Relações Exteriores. Brasília, January 1. http://mundorama.net/2003/01/01/discursoproferido-pelo-embaixador-celso-amorim-por-ocasiao-da-transmissao-docargo-de-ministro-de-estado-das-relacoes-exteriores-brasilia-brasil01012003. Accessed July 7, 2011.

— 2008. Brasil pode suspender crédito a vizinhos. Estado de São Paulo, December 3.

Armijo, Leslie Elliott. 2007. The BRICs Countries (Brazil, Russia, India, and China) as Analytical Category: Mirage or Insight? Asian Perspective 31, 4: 7-42.

Arraes, Virgílio. 2006. O Brasil e a ONU de 1990 a nossos dias: das grandes conferências às grandes pretensões. In Relações internacionais do Brasil. Temas e agendas, vol. 2, ed. Henrique Altemani and António Carlos Lessa. São Paulo: Saraiva. 7-41.

Bouzas, Roberto, Pedro Da Motta Veiga, and Ramón Torrent. 2002. In-Depth Analysis of MERCOSUR Integration, Its Prospectives and the Effects Thereof on the Market Access of EU Goods, Services and Investment. Report presented to the Commission of the European Communities, Observatory of Globalization, Barcelona. www.opalc.org/images/INRE/in-depth\%20analysis \%20of\%20mercosur\%20integration.pdf. Accessed July 7, 2011.

Brasil. Ministério da Defesa. 2008. Estratégia Nacional de Defesa (END). Brasília. www.fab.mil.br/portal/defesa/estrategia_defesa_nacional_portugues.pdf. Accessed July 7, 2011.

Burges, Sean W. 2005. Bounded by the Reality of Trade: Practical Limits to a South American Region. Cambridge Review of International Affairs 18, 3: 437-54.

- 2006. Without Sticks or Carrots: Brazilian Leadership in South America During the Cardoso Era, 1992-2002. Bulletin of Latin American Research 25, 1: 23-42.

- 2007. Building a Global Southern Coalition: The Competing Approaches of Brazil's Lula and Venezuela's Chávez. Third World Quarterly 28, 7: $1343-58$.

—. 2008. Consensual Hegemony: Theorizing Brazilian Foreign Policy After the Cold War. International Relations 22, 1: 65-84.

Cason, Jeffrey, and Timothy Power. 2009. Presidentialization, Pluralization, and the Rollback of Itamaraty: Explaining Change in Brazilian Foreign Policy Making in the Cardoso-Lula Era. International Political Science Review 30, 2: $117-40$.

Centro Brasileiro de Relações Internacionais-Centro de Estudos de Integração e Desenvolvimento (CEBRI-CINDES). 2007. Força-tarefa "O Brasil na América do Sul." Relatório final. Rio de Janeiro, June. www.cindesbrasil.org/ index.php?option=com_docman\&task=doc_download\&gid=20\&Itemid=41. Accessed July 7, 2011. 
Centro de Estudios Unión para la Nueva Mayoría (CEUNM). 2008. Balance militar de América del Sur 2008. Buenos Aires: CEUNM. www.nuevamayoria. $\mathrm{com} /$ index.php?option $=$ com_content\&task $=$ view\&id=1130\&Itemid $=30$.

The Economist. 2008a. An Economic Superpower, and Now Oil Too. April 17.

- 2008b. Brazil's Foreign Policy: The Samba Beat, with Missteps. December 18 .

Etzioni, Amitai. 1975. A Comparative Analysis of Complex Organizations: On Power, Involvement, and Their Correlates. New York: Free Press.

European Commission. 2007. Communication from the Commission to the Council and the European Parliament: Towards an EU-Brazil Strategic Partnership (COM 281). Brussels, May 30. http://ec.europa.eu/external_relations/ brazil/docs/com07_281_en.pdf. Accessed July 7, 2011.

Flemes, Daniel. 2007. Emerging Middle Powers' Soft Balancing Strategy: State and Perspectives of the IBSA Dialogue Forum. GIGA Working Paper 57. Hamburg: German Institute of Global and Area Studies. www.giga-hamburg. $\mathrm{de} / \mathrm{dl} /$ download.php?d=/content/publikationen/pdf/wp57_flemes.pdf.

Garcia, Marco Aurélio. 2008. Gobierno ecuatoriano cometió un error muy grave. El Comercio (Quito), November 22.

Gauthier, Amélie, and Sarah John de Sousa. 2006. Brazil in Haiti: Debate over the Peacekeeping Mission. FRIDE Comment, November. www.fride.org/ download/COM_BraHaiti_ENG_nov06.pdf. Accessed July 7, 2011.

O Globo (Rio de Janeiro). 2010. Serra se diz cético quanto ao Mercosul. September 10. http://oglobo.globo.com/pais/mat/2010/09/10/serra-se-dizcetico-quanto-ao-mercosul-917600935.asp. Accessed July 7, 2011.

Gratius, Susanne. 2007. Brazil in the Americas: A Regional Peace Broker? FRIDE Working Paper 35, April. Fundación para las Relaciones Internacionales y el Diálogo Exterior. www.fride.org/descarga/WP35_BraAmer_ENG_abr07.pdf. Accessed July 7, 2011.

Hakim, Peter. 2002. Two Ways to Go Global. Foreign Affairs 81, 1: 148-62.

Higgott, Richard. 2007. Alternative Models of Regional Cooperation? The Limits of Regional Institutionalization in East Asia. In European Union and New Regionalism: Regional Actors and Global Governance in a Post-Hegemonic Era, ed. Mario Telò. Aldershot: Ashgate. 75-106.

Hirst, Monica. 2007. South American Intervention in Haiti. FRIDE Comment, April. Hurrell, Andrew, Andrew F. Cooper, Guadalupe González González, Ricardo Ubiraci Sennes, and Srini Sitaraman. 2000. Paths to Power: Foreign Policy Strategies of Intermediate States. Working Paper no. 244. Washington, DC: Woodrow Wilson International Center Latin American Program.

International Institute for Strategic Studies (IISS). 2006. The Military Balance 2006. Oxford: Oxford University Press.

Inter Press Service. 2005. Paraguay: U.S. Military Presence Stirs Speculation. August 4. www.commondreams.org/headlines05/0804-08.htm. Accessed March 10, 2009.

Jaguaribe, Helio. 2001. La opción de hierro. Consolidar y expandir el Mercado Común del Sur. Encrucijadas 1, 4: 26-39.

Jordaan, Eduard. 2003. The Concept of a Middle Power in International Relations: Distinguishing Between Emerging and Traditional Middle Powers. Politikon: South African Journal of Political Studies 30, 2: 165-81. 
Kennan, George F. 1993. Around the Cragged Hill: A Personal and Political Philosophy. New York: Norton.

Keohane, Robert O. 1969. Lilliputian Dilemmas: Small States in International Politics. International Organization 23, 2: 291-310.

Lafer, Celso. 2001. A identidade internacional do Brasil e a politica externa brasileira. São Paulo: Perspectiva.

Lima, Maria Regina Soares de. 2008. Brazil Rising. Multipolar World, Internationale Politik (Fall): 62-67.

Lima, Maria Regina Soares de, and Monica Hirst. 2006. Brazil as an Intermediate State and Regional Power: Action, Choice, and Responsibilities. International Affairs 82, 1: 21-40.

Malamud, Andrés. 2005. Mercosur Turns 15: Between Rising Rhetoric and Declining Achievement. Cambridge Review of International Affairs 18, 3: 421-36.

Malamud, Andrés, and Pablo Castro. 2007. Are Regional Blocs Leading from Nation States to Global Governance? A Skeptical View from Latin America. Iberoamericana: Nordic Journal of Latin American and Caribbean Studies 37, 1: 115-34.

Mattli, Walter. 1999. The Logic of Regional Integration: Europe and Beyond. Cambridge: Cambridge University Press.

Newsweek. 2008. Weathering the Storm. July 26. www.newsweek.com/2008/07/ 25/weathering-the-storm.html

Nolte, Detlef. 2007. How to Compare Regional Powers: Analytical Concepts and Research Topics. Paper presented at the ECPR Joint Session of Workshops. Helsinki, May 7-12.

Nye, Joseph. 1990. Bound to Lead: The Changing Nature of American Power. New York: Basic Books.

Pinheiro, Letícia. 2000. Traídos pelo desejo: um ensaio sobre a teoria e a prática da política externa brasileira contemporânea. Contexto Internacional 22, 2: 305-35.

Poggi, Gianfranco. 1990. The State: Its Nature, Development and Prospects. Cambridge: Polity Press.

Russell, Roberto, and Juan Gabriel Tokatlian. 2003. El lugar de Brasil en la política exterior argentina. Buenos Aires: Fondo de Cultura Económica.

Saraiva, Miriam Gomes. 2007. As estratégias de cooperação sul-sul nos marcos da política externa brasileira de 1993 a 2007. Revista Brasileira de Política Internacional 50: 42-59.

—. 2009. O Brasil entre a União Européia e a América do Sul: limites para uma relação triangular. Paper presented at the 28th Conference of the Latin American Studies Association, Rio de Janeiro, June 11-14.

Schirm, Stefan A. 2007. Emerging Power Leadership in Global Governance: Assessing the Leader-Follower Nexus for Brazil and Germany. Paper presented at the ECPR Joint Sessions of Workshops. Helsinki, May 7-12.

Sotero, Paulo, and Leslie Elliott Armijo. 2007. Brazil: To Be or Not to Be a BRIC? Asian Perspective 31, 4: 43-70.

Souza, Amaury de. 2008. O Brasil na região e no mundo: percepções da comunidade brasileira de politica externa. Rio de Janeiro: CEBRI. 
United Nations. 2005. In Larger Freedom: Towards Development, Security and Human Rights for All. Report of the Secretary-General. March 21. www.un.org/largerfreedom. Accessed July 7, 2011.

Vaillant, Marcel. 2007. ¿Por qué Uruguay necesita negociar con Estados Unidos? OBREAL/EULARO Specialist Paper. October. European Union-Latin America Observatory. www.obreal.org/obreal/file.php?idfile=1022. Accessed July 7, 2011.

Vaz, Alcides Costa. 2007. Brasil y sus vecinos: ¿del descubrimiento a la interdependencia? In La percepción de Brasil en el contexto internacional: perspectivas y desafíos. Tomo I: América Latina, ed. Wilhelm Hofmeister, Francisco Rojas, and Luis Guillermo Solís. Rio de Janeiro: Konrad Adenauer Stiftung. 23-40.

Vigevani, Tullo, Gustavo Favaron, Haroldo Ramanzini, and Rodrigo A. Correia. 2008. O papel da integração regional para o Brasil: universalismo, soberania e percepção das elites. Revista Brasileira de Política Internacional 51, 1: 5-27.

Vizentini, Paulo Fagundes. 2006. O G-3 e o G-20: o Brasil e as novas coalizões internacionais. In Relações internacionais do Brasil. Temas e agendas, Volume 2, ed. Henrique Altemani and António Carlos Lessa. São Paulo: Editora Saraiva. 159-93.

Wall Street Journal. 2008. Brazil Joins Front Rank of New Economic Powers. May 13.

— 2009. Economy Fuels Brazil's Ambitions Beyond South America. February 6.

Wilson, Dominic, and Roopa Purushothaman. 2003. Dreaming With BRICs: The Path to 2050. Global Economics Paper no. 99. October 1. New York: Goldman Sachs. www2.goldmansachs.com/ideas/brics/book/99-dreaming.pdf. Accessed July 7, 2011. 
Copyright of Latin American Politics \& Society is the property of Wiley-Blackwell and its content may not be copied or emailed to multiple sites or posted to a listserv without the copyright holder's express written permission. However, users may print, download, or email articles for individual use. 